\title{
'Let's take a look...': An Investigation of Directives as Negotiating Interpersonal Meaning in Engineering Lectures
}

\author{
Heri Kuswoyo ${ }^{1,2 *}$, Eva Tuckyta Sari Sujatna², Lia Maulia Indrayani², Akhyar \\ Rido $^{1}$, and Doris Macdonald ${ }^{3}$
}

${ }^{1}$ Department of English Literature, Faculty of Arts and Education, Universitas Teknokrat Indonesia, Lampung 35132, Indonesia

${ }^{2}$ Department of Linguistics, Faculty of Cultural Sciences, Universitas Padjadjaran, JatinangorSumedang 45363, Indonesia

${ }^{3}$ Department of English, College of Liberal Arts and Sciences, Northern Illinois University, Illinois 60115, USA

\begin{abstract}
The role of directives with command and question speech functions in teaching and learning contexts has received increased attention across a number of disciplines in recent years. This current study was aimed at investigating the use and function of directives with command and question speech functions as a dimension of interpersonal realization in aerospace engineering lectures at Delft University of Technology, Netherlands. Focusing on the English mood system, this study applied Halliday's (1985, 1994) and Eggins's (1994) Systemic Functional Linguistics (SFL) approach. A qualitative content analysis was carried out in four selected content lessons. The data were collected through videotaped recordings as found at cosmolearning.org. The findings showed

ARTICLE INFO

Article history:

Received: 14 October 2020

Accepted: 13 February 2021

Published: 26 March 2021

DOI: https://doi.org/10.47836/pjssh.29.1.03

E-mail addresses:

hery@teknokrat.ac.id (Heri Kuswoyo)

eva.tuckyta@unpad.ac.id (Eva Tuckyta Sari Sujatna)

lia.maulia@unpad.ac.id (Lia Maulia Indrayani)

akhyar_rido@teknokrat.ac.id (Akhyar Rido)

dmvm@niu.edu (Doris Macdonald)

*Corresponding author

that engineering lecturers employed various types of directives. In terms of commands, the lecturers used imperative, declarative, and modulated interrogative moods. In addition, lecturers used interrogative and declarative moods to pose questions. The lecturers used commands to express their attitudes, to organize their messages, to check students' understanding, and to signal the contents of the exams. Meanwhile, in terms of questions, they function to elicit
\end{abstract}


students' background knowledge, to check on students' comprehension, and to handle classroom management issues. The findings of this study can be used by English for Academic Purposes (EAP) professionals, in particular, language lecturers preparing students for the English for Medium Instruction (EMI) study. Also, stakeholders should use the findings of this study as a tool to improve English for English Special Purposes (ESP) teaching and learning in the context of the engineering classroom.

Keywords: Command, engineering lectures, negotiating interpersonal meaning, question, SFL

\section{INTRODUCTION}

Lecturing is the most popular teaching form in university academic courses (Rido et al., 2020; Taghizadeh \& Namayandeh, 2020). During the teaching and learning process, lecturer and student interaction is often required to develop several higherlevel learning outcomes. The language used during classroom interaction has various functions that reflect the meaning of speakers' utterances, such as asking questions and making statements, offers, or commands (Rich, 2016; Walsh, 2011). This is particularly paramount for the advancement of academic learning in which students are challenged to question ideas and concepts to gain a deeper understanding (Moore, 1989; Palma, 2014).

Simultaneously, the language used in a classroom creates particular relationships between lecturer and students to build interpersonal meaning and negotiation to reveal what students feel and think (Komarawan, 2019). Therefore, negotiating interpersonal meaning becomes salient. Through negotiating interpersonal meaning, lecturers interact, take turns, and exchange meaning in roles with students in order to convey ideas and give-receive information effectively (Williams, 2011). Furthermore, negotiating interpersonal meaning is crucial in building talk or dialogue with students (Yuliati, 2012) and of great importance as part of understanding learning and learners' language development (Sahan, 2020; Xuan \& Huang, 2017).

This study discusses the speech role of directive with commands and questions as a means of negotiating interpersonal meaning in the classroom where English is used as the medium of instruction (EMI). Both commands and questions are linguistic elements of interactive lecture discourse; on behalf of students, these can develop and strengthen communicative skills for any speech function (Morell, 2004). In addition, both textual and interpersonal roles occur in commands and questions. They can serve as referential, coherent, organizational instruments, and define the role of the lecturer towards students. The directive with commands and questions is also central to the pedagogical range of lecturers and their effectiveness is essential to the optimization of learning outcomes (Waring \& Hruska, 2012). With regard to commands and questions, Halliday's $(1985,1994)$ systemic functional linguistics (hereafter $S F L$ ) approach to interpersonal meaning is used to identify the English mood system during 
the interactions. English mood concerns "basic interpersonal distinctions in clause types such as declarative, interrogative, and imperative" (Quiroz, 2018, p. 137). As illustrated in Figure 1, English clauses are described as three essential interactions.

The term "mood" refers to the primary interpersonal system of clauses by considering the occurrence of functional mood elements of the subject and finite in a clause (Martin, 2018; Martin et al., 1997). Based on this system, a clause consists of two functional elements, namely mood and residue (Bloor \& Bloor, 2004; Sujatna, 2013). Mood is the combination of the functional constituents of subject and finite of a clause, while residue is the combination of predicator, complement, and/or adjunct of a clause. Research on directives as a realization of negotiating interpersonal meaning with different approaches, such as pragmatics, sociolinguistics, and discourse studies has been conducted.
However, it appears that these approaches are unsatisfactory because they do not take the wider communicative contexts into account. Thus, the present study fills the gap with SFL as an approach to language in its entirety. Such an approach describes language in actual use in texts and their contexts (Ghadessy, 1999; Kuswoyo et al., 2020; Sujatna, 2013).

The key subject of this study is the collaborative dialogue that takes place in English as a medium of instruction (EMI) university contexts, focusing on one aerospace engineering department at a university in the Netherlands, the Delft University of Technology. The Netherlands was chosen as the research context based on two criteria, namely, its ranking as one of the best global universities for engineering in the Netherlands (Morse, 2017) and its high ranking for English language skills (EF English Proficiency Index, 2020). In addition, EMI is increasingly used in

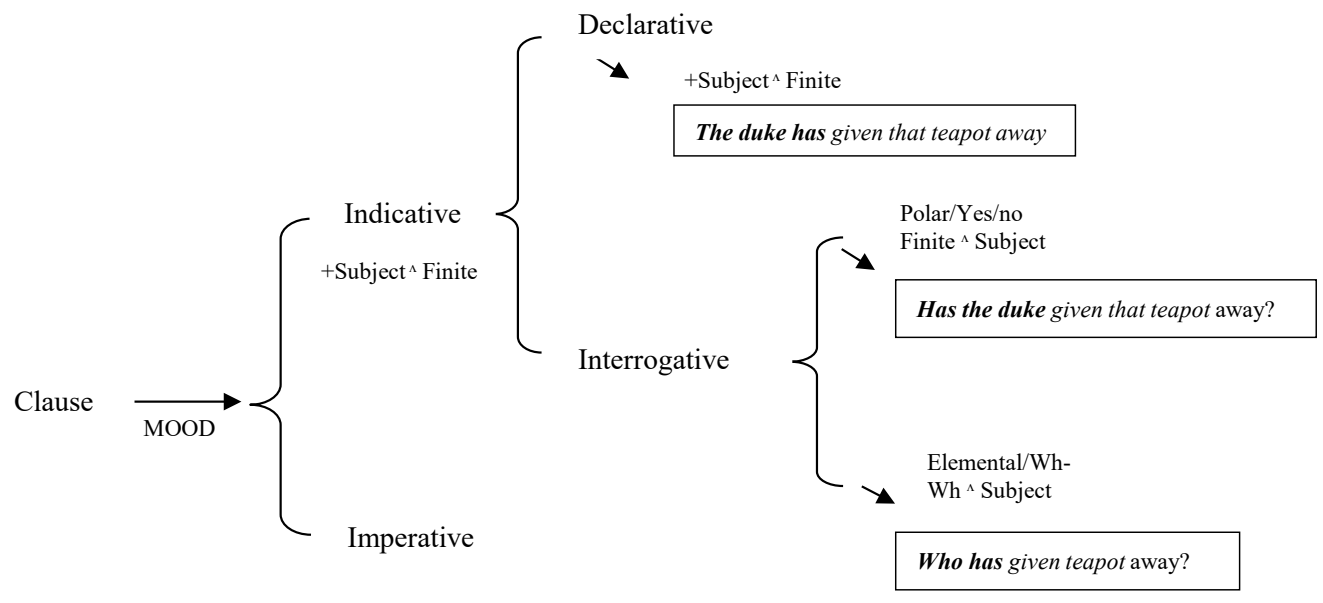

Figure 1. System network for English mood (Halliday, 1985, 1994) 
Dutch engineering lectures (Breetvelt, 2018; Vinke \& Jochems, 1993). In today's world, the engineering discipline has become an essential technical literacy for $21^{\text {st }}$ century (Qadir et al., 2020). As Crystal (2013, as cited in Björkman, 2018) pointed out, English has established itself as the dominant science lingua franca. Moreover, English is the dominant foreign language used as instruction in universities throughout Europe and the world (Soruc \& Griffiths, 2017; Vinke \& Jochems, 1993). Nevertheless, there are some common issues with EMI teaching and studying such as students' inadequate language proficiency, having to educate the indigenous people and teachers, and the lack of foreign host language students' abilities (Coleman, 2006; Rido, 2020). In Mukminin's (2019) study, some Indonesian students studying in Dutch institutions of higher education were found to have faced difficulties due to linguistic issues. The students had trouble using their English in listening, speaking, reading, and writing, which prohibited them for sharing with others. Dearden (2014) added that a lack of resources, the changing role of lectures, and a standard level of EMI teachers were still problematic. Given these findings, this study is necessary to help facilitate the preparation of NNS students in EMI contexts to study since they will interact with lecturers, researchers, and other students from diverse linguistic backgrounds who are engaged in academic work related to that particular field. Therefore, this study was guided by the following research questions:
1. How are command and question speech functions realized in different grammatical moods in engineering lectures?

2. How do commands and questions enhance negotiating interpersonal meaning in engineering lectures?

\section{LITERATURE REVIEW}

\section{Previous studies}

Many studies have become increasingly interested in the realization of directives with commands and questions as an expression of thoughts, opinions, feelings, and attitudes in classroom contexts (Andriany, 2011; Dalton-Puffer, 2005; Sunardi et al., 2018; Waring \& Hruska, 2012). These studies have proven that directives are integral to lecturers' pedagogical repertoire, and their efficacy crucial to optimizing learning outcomes. An early study by Dalton-Puffer (2005) explored directives as an aspect of interpersonal communication management in classrooms where a foreign language was used as a medium of instruction. The study showed that in the Austrian CLIL classroom, students received more indirect and modified requests. In other words, various linguistic moves such polite requests in English were found. In another study, Andriany (2011) examined interpersonal utterances in English as a foreign language classroom in Medan, Indonesia. She noted that the representation by clause system emphasis on interpersonal lexicogrammar in the studied texts indicated that the mood structure of each text was realized either by teachers or students. 
Another study that also looks specifically at directives is that of Waring and Hruska (2012). In their study, they explored issues of clarity and relevance that could render directives problematic and incurred understanding difficulties in pedagogical interaction. Their findings revealed that multiple self-repairs, unspecified references, conflicting messages, and question designs that failed to adequately limit the range of acceptable answers were some factors that could reduce the clarity of a directive. In subsequent work, Sunardi et al. (2018) studied the lexico-grammatical realizations of interpersonal meaning in an Indonesian university's context where English was used as a foreign language. The findings showed that declarative clauses, interrogative clauses, and imperative clauses predominated, but often to serve individuated functions. A teaching-centered approach in classrooms informed the prevalence of the declarative clauses. In addition, the interrogative clause was also used by the lecturer to help students understand the learning materials. Finally, the imperative clause was often used to ask students to do something relevant to the understanding of learning materials.

A number of studies with different frameworks and methodologies have examined directives with commands and questions as an important way of creating conversation or dialog in academic settings with the students and as part of the comprehension of learning in general and language production (Xuan \& Huang, 2017). However, studies dealing with the analysis of negotiating interpersonal meaning in the classroom specifically directives using a SFL approach are limited. What is missing from this growing body of research on directive use in EMI contexts is an investigation of how EMI lecturers construct mood structures in classroom interaction. Thus, this study aims to address this gap in the literature by investigating the importance of the directive as a means of negotiating interpersonal meaning in the classroom.

\section{Conceptual Framework}

This study largely uses a framework of mood structure rooted in Halliday's (1985, 1994) theory, and further developed by Eggins (1994). The SFL framework guides this study and has led to a substantial amount of empirical research on a variety of speech functions and mood systems. SFL considers language as a social semiotic structure, involving experiential, interpersonal, and textual meanings (Halliday \& Matthiessen, 2014). From the interpersonal meaning perspective, language is used to help us engage in interactions with others, take on positions and communicate emotions, behaviors, and thoughts, and to understand them (Eggins, 1994; Fontaine, 2013; Lock, 1996).

This study focuses on the understanding of interpersonal meaning through directives with question and command of the speech functions. With regard to the directive, Eggins (2004) developed a model of typical and non-typical mood in clauses. She proposed, for example, that not all demands for goods and services had to 
be imperatives: commands were typically expressed by imperative clauses but they could also be expressed by declaratives or modulated interrogatives. While questions are usually expressed by interrogatives, they, too, can be expressed by modulated declaratives. Meanwhile, Lock (1996) urged that the category of directives included order, prohibition, suggestions, permissions, and requests. Yet, some linguists (Eggins, 2004; Halliday, 1985, 1994; Schleppegrell, 2013; Thompson, 2014) use different terms. In terms of command, Lock (1996) used directives, and he differentiates between questions and directives. As Table 1 shows, a model of negotiating interpersonal meaning in English directives with commands and questions is elaborated.

Table 1

Model of English directives: Commands and questions (Adapted from Eggins, 2004; Halliday, 1985, 1994)

\begin{tabular}{|c|c|c|c|}
\hline $\begin{array}{l}\text { Speech } \\
\text { function }\end{array}$ & $\begin{array}{l}\text { The typical mood in } \\
\text { clause }\end{array}$ & Ways of interacting & Example \\
\hline \multirow{7}{*}{$\begin{array}{l}\text { Command } \\
\text { (demanding } \\
\text { goods \& } \\
\text { services) }\end{array}$} & $\begin{array}{l}\text { 1. Imperative mood } \\
\text { (typical clause } \\
\text { mood) }\end{array}$ & $\begin{array}{l}\text { to get something done } \\
\text { directly }\end{array}$ & “Read Henry James” \\
\hline & $\begin{array}{l}\text { 2. Declarative mood } \\
\text { (non-typical clause } \\
\text { mood) }\end{array}$ & to get something done & $\begin{array}{l}\text { "I'm hoping you'll read } \\
\text { some Henry James" }\end{array}$ \\
\hline & $\begin{array}{l}\text { 3. } \text { Modulated } \\
\text { interrogative mood } \\
\text { (non-typical clause } \\
\text { mood) }\end{array}$ & $\begin{array}{l}\text { indirect request for } \\
\text { information }\end{array}$ & $\begin{array}{l}\text { "Would you mind } \\
\text { reading Henry James, } \\
\text { please?" }\end{array}$ \\
\hline & $\begin{array}{l}\text { 4. Permission } \\
\text { directive (non- } \\
\text { typical clause } \\
\text { mood) }\end{array}$ & requires an action & "May I have a match?" \\
\hline & $\begin{array}{l}\text { 5. Question Directive } \\
\text { (non-typical clause } \\
\text { mood) }\end{array}$ & $\begin{array}{l}\text { to get something done } \\
\text { indirectly }\end{array}$ & "Got a match?" \\
\hline & $\begin{array}{l}\text { 6. Hints (non-typical } \\
\text { clause mood) }\end{array}$ & $\begin{array}{l}\text { indirect and require } \\
\text { considerable } \\
\text { knowledge of the } \\
\text { situation }\end{array}$ & $\begin{array}{l}\text { "The matches are all } \\
\text { gone" } \\
\text { "I am not really good } \\
\text { prepared for" }\end{array}$ \\
\hline & $\begin{array}{l}\text { 7. Need statement } \\
\text { (non-typical clause } \\
\text { mood) }\end{array}$ & $\begin{array}{l}\text { to mark them as } \\
\text { requests by adding } \\
\text { "please", }\end{array}$ & $\begin{array}{l}\text { "I need a match, } \\
\text { please!" }\end{array}$ \\
\hline
\end{tabular}


Table 1 (Continued)

\begin{tabular}{|c|c|c|c|}
\hline $\begin{array}{l}\text { Speech } \\
\text { function }\end{array}$ & $\begin{array}{l}\text { The typical mood in } \\
\text { clause }\end{array}$ & Ways of interacting & Example \\
\hline & $\begin{array}{l}\text { 8. Wishes (non- } \\
\text { typical clause } \\
\text { mood) }\end{array}$ & $\begin{array}{l}\text { to get something done } \\
\text { indirectly }\end{array}$ & $\begin{array}{l}\text { "What I would like you } \\
\text { to do later is..." }\end{array}$ \\
\hline & $\begin{array}{l}\text { 9. Desires (non- } \\
\text { typical clause } \\
\text { mood) }\end{array}$ & $\begin{array}{l}\text { to get something done } \\
\text { indirectly }\end{array}$ & $\begin{array}{l}\text { "I want you to write a } \\
\text { little heading" }\end{array}$ \\
\hline & $\begin{array}{l}\text { 10. Obligation (non- } \\
\text { typical clause } \\
\text { mood) }\end{array}$ & $\begin{array}{l}\text { to get something done } \\
\text { directly }\end{array}$ & $\begin{array}{l}\text { "You must return it } \\
\text { according to your } \\
\text { catalog number" }\end{array}$ \\
\hline \multirow[t]{2}{*}{$\begin{array}{l}\text { Question } \\
\text { (Demanding } \\
\text { information) }\end{array}$} & $\begin{array}{l}\text { Interrogative } \\
\text { mood (typical } \\
\text { clause mood) }\end{array}$ & $\begin{array}{l}\text { to ask for information } \\
\text { to encourage someone } \\
\text { to think about } \\
\text { something }\end{array}$ & $\begin{array}{l}\text { "Is The Bostonians by } \\
\text { Henry James?" }\end{array}$ \\
\hline & $\begin{array}{l}\text { 2. Modulated } \\
\text { declarative (non- } \\
\text { typical clause } \\
\text { mood) }\end{array}$ & to ask for information & $\begin{array}{l}\text { "I was wondering } \\
\text { whether The } \\
\text { Bostonians might be } \\
\text { by Henry James" }\end{array}$ \\
\hline
\end{tabular}

\section{METHODS}

\section{Research Design}

This study used Krippendorff's (2004) qualitative content analysis, characterized as a research technique for making textual inferences replicable and true in the sense of their use. This study was based on a systematic and analytical method for rational inference from oral, visual, or written knowledge to explain and measure particular phenomena (Downe-Wamboldt, 1992).

\section{Data Collection}

This study was based on the Cosmolearning. org freely available online lecture series (https://cosmolearning.org). Cosmolearning. org is a web platform collection of educational videos from hundreds of universities, educators, and professionals. Four aerospace engineering lectures from the University of Delft in the Netherlands were the main resources for this study. These lectures were chosen because of their scientific content and because English is used as the medium of instruction for this subject. The lecturers in these videos are all fluent, though non-native speakers of English, three males, and one female. There are two limiting factors in the analysis that should be noted: (1) this study used only transcripts, focusing on analyses of mood structures while recognizing that non-verbal, 
visual and prosodic clues are also part of the complete lecture setting; (2) following Siepmann (2005), as is typical for research on ready-made corpora, there was no data triangulation. This study is, therefore, based on judgments of plausibility rather than on certainty (Mann \& Thompson, 1998, as cited in Deroey \& Taverniers, 2012). Table 2 presents a description of the lectures used in this study. These lecturers will be referred to by their initials throughout.

Creswell (2009) noted that any qualitative study should choose participants or sites deliberately to help researchers better understand the problem and research problems, including video and visual content. Regarding the criteria for data selection, the video recorded lectures were collected from https://cosmolearning.org and distributed across four broad themes: (1) Ballooning (JH) (https://cosmolearning. org/video-lectures/introduction-aero-engballooning/), (2) How aircraft fly (JS) (https://cosmolearning.org/video-lectures/ how-airplanes-fly/), (3) Fundamentals of aerodynamics (HB) (https://cosmolearning. org/video-lectures/aerodynamics-1fundamentals/), and (4) Flight mechanics (MV) (https://cosmolearning.org/videolectures/flight-mechanics-1-introduction/).

All four video-recorded lessons were first transcribed verbatim manually. After that, they were transcribed into text format using YouTube auto-transcribe service. The decision was made to use this feature because it provides highly accurate, consistent, and quality transcription (Adrina, 2019).

Table 2

Description of lecturers in the current study

\begin{tabular}{lllll}
\hline $\begin{array}{l}\text { Transcripts } \\
\text { Number (label) }\end{array}$ & $\begin{array}{l}\text { Participants } \\
\text { (initials) }\end{array}$ & Gender & Topic/title & Duration \\
\hline L1_AeEn & JH & Male & Ballooning & 1 \\
& & Male & How aircraft fly & $1: 26: 13$ \\
L2_AeEn & JS & Female & $\begin{array}{l}\text { Aerodynamic } \\
\text { fundamentals }\end{array}$ & $1: 26: 09$ \\
L3_AeEn & HB & Male & Flight Mechanics & $1: 28: 19$ \\
L4_AeEn & MV & & & \\
\hline
\end{tabular}

\section{Data Analysis}

The data analysis in this study was carried out in four steps: decontextualization, recontextualization, categorization, and compilation. The decontextualization stage included accessing, downloading, and transcribing the videotaped lectures the manual and audio transcriptions were checked for accuracy and read in their entirety for cohesion. Next, the relevant 
meaning units were identified and then the coding for each of these used an open coding procedure. A sample of the coding scheme of transcribed text is illustrated in Table 3 .

After open-coding of the data was completed, similar characteristics in the data set were identified and classified. The transcribed utterances were divided into question clauses and command clauses based on the mood system suggested in Halliday (1985, 1994) and Eggins (1994). At the contextualization stage, the original texts were reread alongside the final list of units of meaning to check that all aspects of the material were addressed concerning the research questions. The third stage is categorization. In this stage, the authors identified themes and categories rooted in the data from which they arise. Finally, the compilation of data included a summary of themes, categories, or sub-themes presented in tabular format (Bengtsson, 2016). To ensure validity of the data sorting, a peer debriefing and an independent accuracy check by a linguistic expert not involved in the data gathering process were undertaken. Table 4 presents an example of how data were organized and presented; in this example, an imperative form is used with an advisory function.

Table 3

Sample coding of transcribed text data

\begin{tabular}{|c|c|c|c|c|}
\hline $\begin{array}{l}\text { Data } \\
\text { No. }\end{array}$ & $\begin{array}{l}\text { Meaning Unit } \\
\text { (Utterances) }\end{array}$ & $\begin{array}{l}\text { Condensed } \\
\text { meaning unit } \\
\text { (Clauses) }\end{array}$ & Category & Coding \\
\hline Im_03/I & $\begin{array}{l}\text { So let's change this } \\
\text { formula! We know that } \\
\text { the air density is by mass } \\
\text { divided by volume, which } \\
\text { means that the volume is } \\
\text { mass divided by density. }\end{array}$ & $\begin{array}{l}\text { Let's change this } \\
\text { formula. }\end{array}$ & Command & $\begin{array}{l}\text { Use } \\
\text { imperative } \\
\text { (typical } \\
\text { clause) }\end{array}$ \\
\hline
\end{tabular}

Table 4

Example of data presentation

\begin{tabular}{lccccc}
\hline & \multicolumn{2}{c}{ Mood } & \multicolumn{3}{c}{ Residue } \\
\cline { 2 - 5 } Function & Subject & Finite & Predicator & Complement & Adjunct \\
\hline Advice & & & Remember & that! & \\
\hline
\end{tabular}




\section{RESULTS}

In this section, the findings from the analysis of directives with commands and questions in EMI engineering lectures are presented. These directives manifest various grammatical moods and functions in the dimensions of interpersonal interaction in aerospace engineering lectures.

Table 5 presents the different categories of command and question functions in the data as they relate to various grammatical moods. Commands in these aerospace engineering lectures were found to be manifested through imperative, interrogative, and declarative mood structures. The function of each sub-mood type "directive" is also presented in Table 5. A thorough discussion of grammatical moods and their functions in the data follows.

\section{Table 5}

Summary of English directives in the aerospace engineering lectures

\begin{tabular}{l}
$\begin{array}{l}\text { Commands } \\
\text { (Demanding Goods \& Services) }\end{array}$ \\
\hline 1. Imperative Mood (Typical mood clause) \\
a. $\quad$ Advice \\
\\
"So please also remember these!" \\
b. $\quad$ Wemember that! We said that." \\
"Don't ask me why they did it." \\
"Don't study it too intensively." \\
"Please be aware!" \\
Instruction \\
"Let's change this formula!" \\
"So take out your notebook." \\
"Let's go to the first force!"
\end{tabular}

2. Declarative Mood (Non- typical mood clause)

a. Obligation

"You have to be able to understand all the forces."

Questions

(Demanding Information)

1. Interrogative Mood (Typical mood clause)

a. Request (Wh-Interrogative) "How many passengers do you think travel annually by air?" "What's the general principle?"

b. Confirming or denying information (Yes/No Question) "Does that make sense?"

2. Declarative Mood (Non- typical mood clause)

\section{a. Request}

"There are three general principles."

"There is a little functional feeling in the atmosphere but there is another way."

"So you have to understand all the forces that act on the aircraft."

b. Necessity

"You really should remember it also for the exam."

"You can use some kind of snowball effects." 


\begin{tabular}{ll}
$\begin{array}{l}\text { Commands } \\
\text { (Demanding Goods \& Services) }\end{array}$ & $\begin{array}{l}\text { Questions } \\
\text { (Demanding Information) }\end{array}$ \\
\hline
\end{tabular}

3. Modulated Interrogative Mood (Nontypical mood clause)

a. Permission Directive

"Can I now just integrate and do something in general or not?"

b. Question Directive

"Maybe could you please go to the service desk and ask for new batteries for my microphone, please?"

\section{Command Speech Functions}

This section presents not only the function and categories of command but also the grammatical moods instantiating them in the aerospace engineering lectures studied. Grammatical mood encodes how the conditions are arranged to offer interpersonal meanings such as challenges, agreements, statements, refusals, among others. The discussion also aims at highlighting the connection between the semantic organization, the mood structure of the clauses, and grammar differences. Within clauses of various mood forms, the authors then define the functional elements and their configurations. As noted earlier, two constituents are established in interpersonal meaning: mood and residue. Mood is defined as the primary interpersonal system of clauses by considering the occurrence of functional mood elements of the subject and finite in a clause. Meanwhile, the residue is merely what is "left over" once the mood has been established. Residue is the combination of predicator, complement, and/or adjunct of a clause.

\section{Imperative Mood.}

The use of imperative in the classroom is influenced by the role relationships among lecturer and students. As the center of the teaching-learning activities, the lecturer is responsible for students' understanding of the learning materials. In this context, the lecturer is entitled to ask students to do something related to their understanding of the learning materials. These roles are consistent with Lock's (1996) descriptions. In many contexts, directives are expressed by imperative mood as commands or orders, which the speaker expects to be obeyed. This study demonstrates that the engineering lecturers used imperative moods for advice, warning, and instruction as illustrated in Table 6.

\section{Advice}

Here, the lecturers made commands using the imperative mood consisting of only a residue or no mood element at all. As is typical for the imperative, the subject is not specified since it can only be the addressee 
Table 6

Imperative mood used in engineering lectures

\begin{tabular}{lccccc}
\hline \multirow{2}{*}{ Function } & \multicolumn{2}{c}{ Mood } & \multicolumn{3}{c}{ Residue } \\
\cline { 2 - 5 } Advice & Subject & Finite & Predicator & Complement & Adjunct \\
Warning & & & Remember & that! & \\
& & Don't & study & it & too \\
Instruction & Let's & & & intensively: \\
& & circumstantial & to the first \\
& & & & force: \\
& & & & & circumstantial \\
\hline
\end{tabular}

"you." The lecturers used mood types that function as advice using the element of residue only. For example, in Excerpt 1, the lecturer attempts a demand intended to influence student behavior.

\section{Excerpt 1}

1. Remember that! We said that the pressure inside and outside is approximately the same (Im_15/I)

In this example, the lecturer and students are discussing pressure, which previously has been explained. The lecturer then directly orders students to review, referring to the earlier lesson, thereby making a connection between the current activity and a specific previous lesson. As Lee (2016) reported, such a strategy is important because students would be more confident in performing activities with which they were familiar. By making intertextual links between the current activity and a specific classroom event in the past, lecturers further maintain the course continuity.

\section{Warning}

In implementing an imperative mood, engineering lecturers also used it as a warning. This imperative consists of a finite negative mood element only, also with no overt subject illustrated in Excerpt 2.

\section{Excerpt 2}

2. We can also ask about this but don't study it too intensively. Don't study it for all the older dates and so on (Im_1/II)

In the discussion of the history of aircraft, the command not to study "too intensively" comes as a response to a student's question. The goals of this lecturer's command are predominantly facts concerning the content, while the questions asked by students are concerned mostly with exams. Thus, it is natural for the lecturer to use this mood system since he is in control of the classroom. 


\section{Instruction}

This kind of mood type was the most frequently used by the engineering lecturers. In excerpt 3 , the lecturer ordered the students using elemental subject of mood let's. The subject refers not only "you" but also "you and me." Halliday and Matthiessen (2014, p. 166) argued that "'let's' itself' is best interpreted as a wayward form of the subject."

\section{Excerpt 3}

3. Let's go to the first force! I first I would like to talk about the lift, the lift over aircraft. (Im_24/II)

In Excerpt 3, the lecturer and students discussed three main components of force: the empty weights that structure all systems, such as lift, drag, and thrust. In this context, the lecturer told the students they would discuss these components one at a time. It implies that the clause is structured to enable the speaker to express opinion and attitude; as Morell (2004) found, a command can function both textually and interpersonally.

\section{Declarative Mood.}

Demands for goods and services are typically (but by no means always) realized by imperatives (Eggins, 2004). They can be also realized by declaratives. The findings (refer Table 7) demonstrate that the lecturers used the declarative mood mainly to encode obligation and necessity.

\section{Obligation}

The findings show that the lecturers also used declarative mood to indicate obligation. Ervin-Tripp (1976) noted that any declarative or interrogative was to be interpreted as a command to be executed if it related to an event or operation within the remit of the addressee.

Table 7

Declarative mood used in declarative lectures

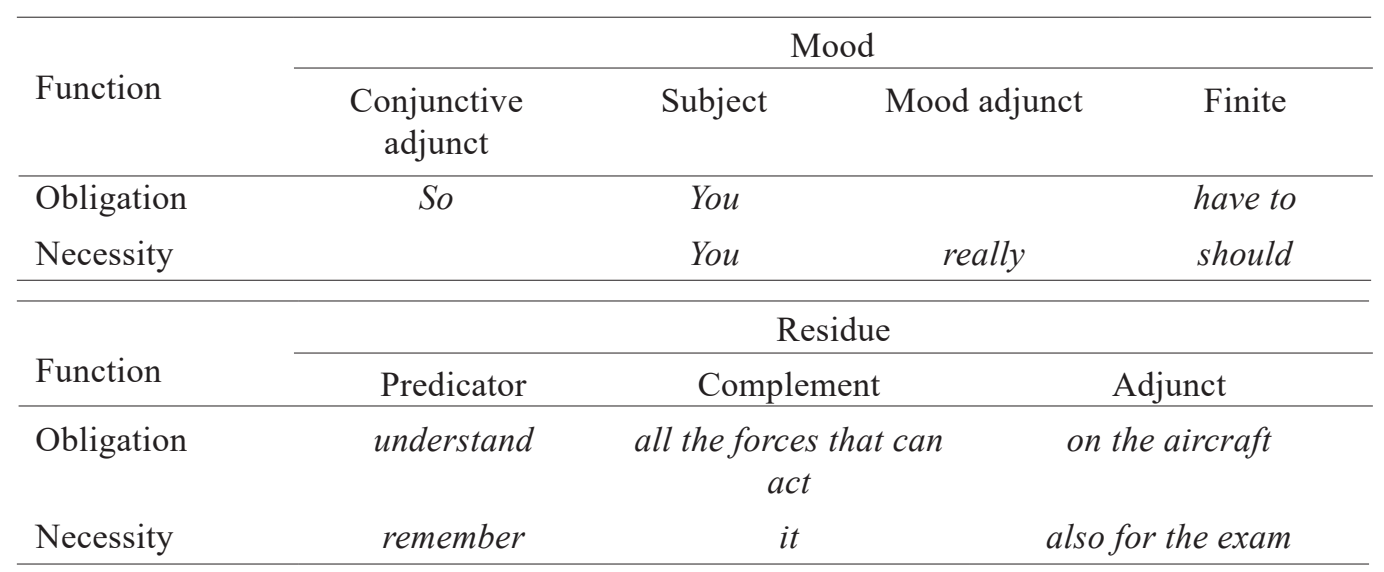




\section{Excerpt 4}

4. So, you have to be able to understand all the forces that act on the aircraft. (Dec_27/IV)

In Excerpt 4, MV, in explaining equations of motion of an aircraft, asserts that students must understand the forces first. In this context, MV obviously gave a command to students by realizing the proposal in the form of a modulated declarative mood clause Subject ${ }^{\wedge}$ Finite. It can be most clearly seen in his utterances "you have to." Moreover, as Iedema (1997) noted, obligation ("have to") is realized incongruently as "important,", and the implication is that $\mathrm{MV}$, is obligating learners to understand the foundational material before he proceeds to the next discussion. In addition to this obligation function, the lecturer can also use a declarative to encode necessity, as indicated by HB's modulated finite "should" in Excerpt 5.

\section{Necessity}

The goals of using a declarative with a modal finite expressing necessity are to order the addressee to do something; the speaker is putting forward an opinion about whether or not that something should be done (Butt et al, 2000).

\section{Excerpt 5}

5. You really should remember it also for the exam (Dec_15/III)

In excerpt 5, HB explains one of the formulas, highlights it visually, and verbally associates it with the contents of an upcoming exam. Here HB chose the declarative mood clause to realize the meaning, with modulated finite "should," expressing not a probability but a necessity (Eggins, 2004).

\section{Modulated Interrogative Mood.}

The findings show that engineering lecturers not only used imperative and declarative moods but also modulated interrogative mood. In the Table 8, the lecturer ordered permission and action of the students by using modal finite "can" and "could." In terms of "permission." Blum-Kulka et al. (1989) and Dalton-Puffer (2005) distinguished between actions, products, permissions, and information as forms of request objectives. The current findings indicate that the most direct demands for action are made. Further, the research results show that requests for action are most direct.

\section{Permission Directive}

Excerpt 6

6. Can I now just integrate and do something in general or not? (PerDir_1/III)

Lecturer HB, in Excerpt 6, is discussing pressure density and velocity. Here she appears to be asking permission from the students to integrate and do something the material into the general, using a conventionally indirect a modal finite can. Eggins (2004) stated that imperative was not only the types of speech function that demanded action as a question directive such as this might also function this way. 


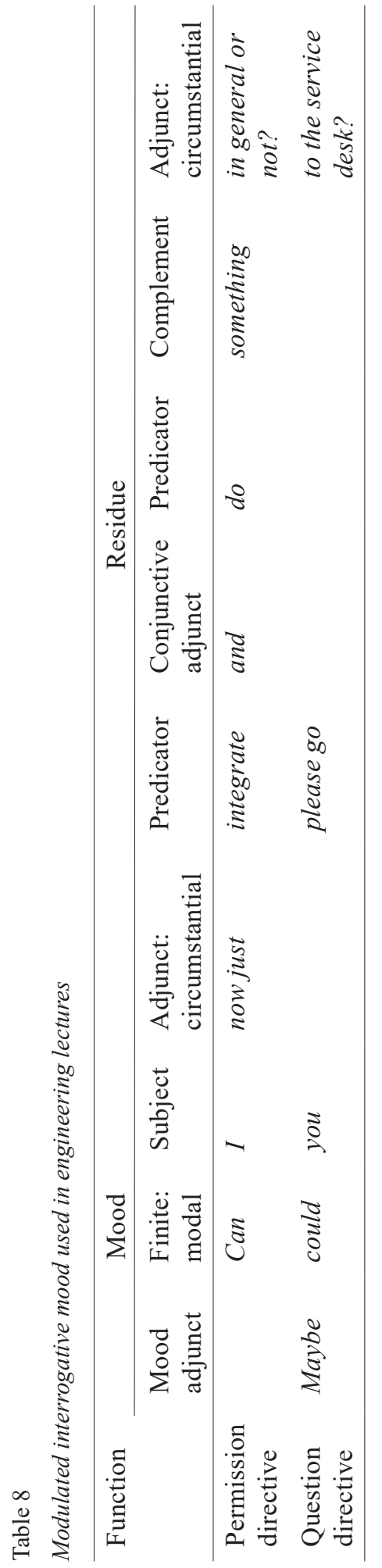

A second type of modulated interrogative mood found was the question directive. The following data shows how the engineering lecturer used the finite "could" to demand actions.

\section{Question Directive}

Excerpt 7

7. Maybe could you please go to the service desk and ask for new batteries for my microphone please! (ModIn_1/I)

Excerpt 7 shows that JH ordered the student's action. He directed a student to get some new batteries since, in his explanation, his microphone did not work. After a few minutes, the student returned to the class with new batteries. As Ervin-Tripp (1976) noted, the question directive gives listeners an out by explicitly stating some condition that would make compliance impossible. It seems clear that JH chose this kind of mood according to his judgment regarding his power, social distance, and right to impose on another.

\section{Question Speech Functions in Engineering Lectures}

Question speech function refers to the types of grammatical mood used by engineering lecturers in the corpus studied. In terms of question speech functions, the findings show that the engineering lectures used interrogative Mood for requesting and confirming or denying information and declarative mood for requesting. 


\section{Interrogative Mood.}

\section{Wh-Interrogative}

The Wh-interrogative structure was the most frequently used by engineering lecturers. In the following excerpt, the engineering lecturer asked the students Wh-interrogatives with a finite "do." Questions realized with a Wh-interrogative clauses request specific pieces of information. For Whinterrogatives, the residue is split, coming in past before the mood and completing after the mood as in Table 9.

\section{Excerpt 8}

8. How many passengers do you think to travel annually by air? (Inter_1/I)

Excerpt 8 is from a discussion among students and $\mathrm{JH}$ of transportation aeronautics. To build or elicit students' background knowledge, JH asked open referential questions with finite "do" and began by using a circumstantial adjunct, "How many passengers." He posed the question to the entire class. This strategy is in line with Lee's (2016) findings that, as teachers attempt to activate students' knowledge, they invite them to jointly reconstruct this knowledge through a series of teacher-student exchanges. Furthermore, Rido (2017) had noted that open referential questions were used not only to evaluate the students reading skills critically but also to elicit unknown information and get longer responses.

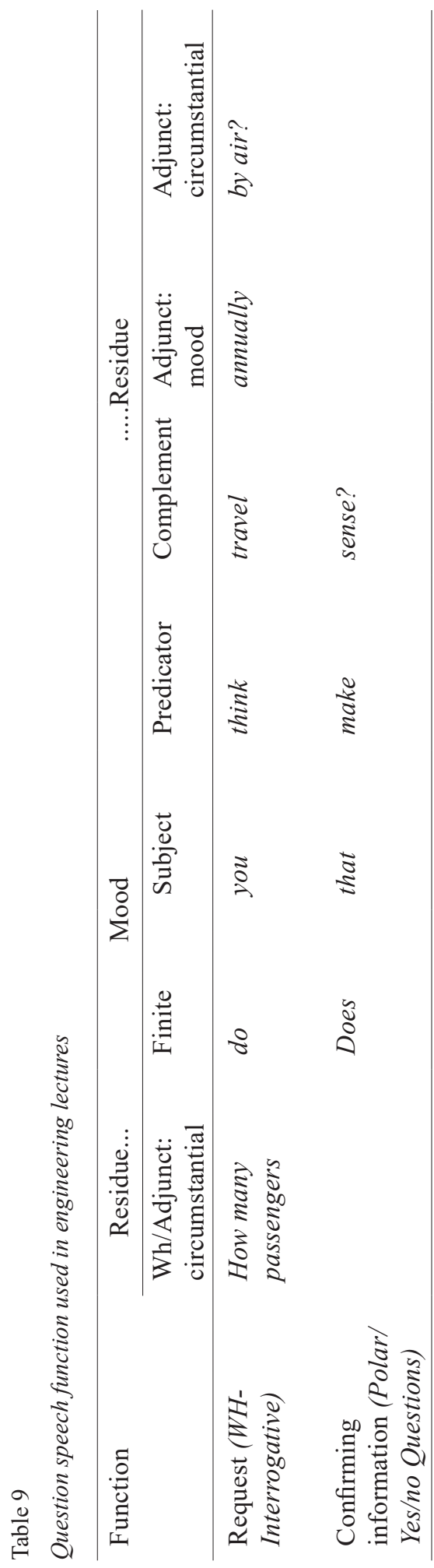




\section{Polar Interrogative}

The following excerpt shows how the engineering lecturers posed elided questions (yes/no question) with adjunct polarity, "Yes," and complement "question." This kind of question requires confirmation or denying information.

Excerpt 9

9. Yes, question? (Int_32/II)

\section{Excerpt 10}

10. Does that make sense? (Int_36/II)

Excerpts 9 and 10 show JS asking students elided questions, "Yes, question?" and yes/ no questions, "Does that make sense?" to check on students' comprehension. Richards \& Lockhart (1996, in Lee, 2016) stated that they had used it to handle classroom procedures and management issues rather than the lesson's content. Additionally, it functions as "punctuation" informing students that the instructions should be clear, so they should be ready to proceed. Asking a polar interrogative can identify how far students understand the material; it can also monitor learning and encourage students to use the target language in the form of verbal responses (Rido, 2017).

\section{Declarative Mood.}

A question refers to any stretch that functions to elicit information from the addressee (Thompson, 2014). In other words, it is usually expressed by interrogative (Eggins, 2004). Typically, it has an ordering of the two elements of Finite`Subject. Eggins (2004) added that a question could be expressed not only by an interrogative but also by a modulated declarative. However, modulated declaratives were not found in this typical mood. This is in line with the findings Fikri et al. (2014), who did not find it in a question speech function, rather in a statement speech function, such as "First of all, I would like to inform you...." On the other hand, this study revealed that interrogative mood could also be expressed by declarative mood question as illustrated in Table 10 and Excerpt 11.

\section{Excerpt 11}

\section{There are three general principles? (ModDec2/I)}

Here JH poses an open referential statement to the entire class to ask how to generate lift, after which a student answers incompletely. In his explanation, $\mathrm{JH}$ then signals the answer by uttering, "There are three general principles?" Such a question normally

Table 10

Declarative mood question used in engineering lectures

\begin{tabular}{lccc}
\hline Function & \multicolumn{2}{c}{ Mood } & Residue \\
\cline { 2 - 4 } & Subject & Finite & Complement \\
\hline Question & There & are & three general principles \\
\hline
\end{tabular}


expects confirmation as a response. As Eggins (2004) stated, this was categorized as a non-typical mood clause because a common question was expressed by Finite ${ }^{\wedge}$ Subject. However, the current findings show that it is formed as Subject $\wedge$ Finite. In addition, in such a declarative Mood question, rising intonation and context must always be taken into account.

\section{DISCUSSION}

The aim of this study was to investigate how lecturers used directives with commands and questions to negotiate interpersonal meaning in EMI aerospace engineering lectures. The current study also examined grammatical mood of command and question. The results indicate that lecturers used various mood clauses to instantiate a variety of meanings/functions. In terms of command, lecturers applied three kinds of mood namely, imperative, declarative, and modulated interrogative. The findings have suggested that lecturers use them to express their attitude and opinion, such as giving advice, warning, or instruction, and also encoding obligation, necessity, permission, and questions.

In the extracts presented above, typical imperative with the mood marker "let's" was frequently used, largely to issue orders or to instruct. The use of that kind of mood demonstrates how lecturers and students do something relating to the understanding of the learning contents or materials. This in keeping with Dalton-Puffer's (2005) findings, where the use of inclusive firstperson plural (the "us" of "Let's") casts lecturer and students as a group already en route together. It can be argued that the imperative mood found as the most used in the present study was in contrast with the finding of Andriany (2011) and Sunardi et al. (2018), who found interrogatives were used more than imperatives. In addition, command speech function was realized by declarative mood. This finding is consistent with Eggins' (2004) theory that demands for goods and services are typically realized by imperatives but can also be realized by declaratives. It is worth noting that declarative mood is categorized as a nontypical mood clause with two functions, obligation and necessity.

With regard to obligation, the findings of this study confirm Iedema's (1997) findings that attribute modulated finite "have to" as an important mood clause element. For example, "You have to be able to understand all the forces that act on the aircraft" indicates that the engineering lecturer obligated his students to understand that topic first before they continued discussing another topic. In addition, the function of necessity also signals important information that should be known by students, as can be seen in clause, "You really should remember." As Eggins (2004) reported, the modulated mood "should" indicated a meaning of necessity. Another non-typical mood found in the command speech function is modulated interrogative mood, used by the engineering lecturers to request permission and action. In terms of permission, the findings of this study confirm those of Blum-Kulka et al. (1989) 
and Dalton-Puffer (2005) as distinguishing between action, products, permissions, and information as forms of request. This finding also accords with Eggins's (2004) theory, which shows that the imperative is not the only speech function type but is complemented by use of the modulated interrogative with indirect demand or speaker-based condition.

Meanwhile, in terms of questions, lecturers employed two kinds of mood, interrogative and declarative. These function as requesting specific information and confirming or denying information. Both Wh-interrogatives and polar interrogatives were found, and this is consistent with previous observational studies (Lee, 2016; Rido, 2017) in which Wh-interrogatives were employed in attempts to activate students' knowledge, to elicit unknown information, and to check students' understanding. The engineering lecturers also used polar interrogatives to check students' understanding and to handle classroom management. In terms of declarative mood, however, the results of the current analysis have not previously been described. A possible explanation for this might be that interrogative function can also be expressed by declarative mood. The clause "there are three general principles" for example, indicated a question speech function. In doing so, however, rising intonation and context must be considered. This finding may help us to find new ways of building interaction with students. To this end, modulated declarative mood was not found. The findings do not correspond with
Eggins's (2004) theory, which identified modulated declarative as the question speech function. It can be argued that engineering lecturers mostly used interrogative not only to ask for information but also to encourage students to think about something. Thus, the findings suggested that Wh-interrogative was frequently used to build or elicit students' knowledge and engagement with the material.

\section{CONCLUSION}

In conclusion, aerospace engineering lecturers used various types of directives with commands and questions. They involve typical and non-typical mood clauses. The lecturers shared a large number of types of commands comprising imperative, declarative, and modulated interrogative moods. At the same time, the lecturers used two types of mood clauses, interrogative and declarative. The findings from this study suggest that lecturers and students exchange interpersonal meaning through various grammatical moods with their varying communicative functions. Notably, this variety of form and function could enhance negotiating interpersonal meaning to create an interactive learning and increased learner comprehension.

There are some implications of choosing command and question speech functions in aerospace engineering lectures. Commands seemed to fulfill their function not only to express opinion and attitudes but also to organize a message, to review earlier lessons, to ensure students' common knowledge base, to signal important information 
related to the contents of the exam, and to exert power, distance, and imposition. Meanwhile, questions functioned to build or elicit students' background knowledge, to jointly reconstruct knowledge through a series of teacher-student exchanges, to evaluate the students' speaking skills, to elicit unknown information and get longer responses, to check student comprehension, and to handle classroom procedures and management issues.

The results of the study are useful in many ways. First, the findings of this study contribute to a pedagogical discourse that can be realized in two sets of language choices, such as regulative register (dealing with teaching-learning activity's goals, aims, and directions) and instructional register (dealing with the "material" to be taught and learned). Second, stakeholders can also use the findings of this study as a tool to improve foreign language learning in the context of the engineering (or other science-based) classroom. Third, EAP practitioners and programs working to prepare students for EMI study may consider an SFL approach to language learning and teaching that reflects the realization of grammatical mood through negotiating interpersonal meaning.

To this end, this study has yielded some interesting results; however, these findings are limited in two ways. First, this paper investigated only a particular discipline of engineering, aerospace engineering, and further studies should look at various disciplines and various EMI contexts. Second, the study was constrained to an in-depth analysis of a limited number of lectures, and future research could engage larger corpora to get a fuller picture of the interaction of mood types and interpersonal classroom effects.

\section{ACKNOWLEDGEMENT}

We would like to thank Universitas Padjadjaran and Northern Illinois University for their support which has facilitated the preparation of this work. Our thanks also go to the Ministry of Education and Culture of the Republic of Indonesia for BPP-DN Scholarship and PKPI/Sandwich-like Program. Thanks are also due to Universitas Teknokrat Indonesia for administrative support. We would also like to thank the anonymous reviewers for their fruitful comments and constructive feedback.

\section{REFERENCES}

Adrina, J. (2019, December 22). What is the best transcription service for YouTube videos? Quora. https://www.quora.com/What-is-thebest-transcription-service-for-Youtube-videos

Andriany, L. (2011). Ujaran interpersonal dalam wacana kelas: Analisis linguistik sistemik fungsional [Interpersonal utterances in classroom discourse: Systemic functional linguistic analysis; Doctoral dissertation, Universitas Sumatera Utara]. University of Sumatera Utara Institutional Repository. http://repository.usu. ac.id/handle/123456789/28991

Bengtsson, M. (2016). How to plan and perform a qualitative study using content analysis. Nursing Plus Open, 2, 8-14. https://doi.org/10.1016/j. npls.2016.01.001

Björkman, B. (2018). English as a lingua franca in spoken genres in the international university: Introduction. Journal of English as Lingua 
Franca, 7(2), 225-228. https://doi.org/10.1515/ jelf-2018-0019

Bloor, T., \& Bloor, M. (2004). The functional analysis of English: A Hallidayan approach. Arnold.

Blum-Kulka, S., House, J., \& Kasper, G. (1989). Cross cultural pragmatics: Requests and apologies. Aplex Publishing Corporation. https://doi. org/10.2307/415556

Breetvelt, I. R. I. S. (2018). English-medium instruction in Dutch higher education: A policy reconstruction and impact study. L1 Educational Studies in Language and Literature, 18, 1-24. https://doi.org/10.17239/L1ESLL-2018.18.03.10

Butt, D., Fahey, R., Feez, S., Spinks, S., \& Yallop, C. (2000). Using functional grammar: An explorer's guide (2nd ed.). National Centre for English Language Teaching and Research.

Coleman, J. A. (2006). English-medium teaching in European higher education. Language Teaching, 39(1), 1-14. https://doi.org/10.1017/ S026144480600320X

Creswell, J. W. (2009). Research design: Qualitative, quantitative, mixed methods approaches (3rd ed.). SAGE Publications.

Dalton-Puffer, C. (2005). Negotiating interpersonal meanings in naturalistic classroom discourse: Directives in content-and-language-integrated classrooms. Journal of Pragmatics, 37(8), 1275-1293. https://doi.org/10.1016/j. pragma.2004.12.002

Dearden, J. (2014). English as a medium of instruction-a growing global phenomenon: Phase 1. British Council.

Deroey, K. L. B., \& Taverniers, M. (2012). Just remember this: Lexicogrammatical relevance markers in lectures. English for Specific Purposes, 31(4), 221-233. https://doi.org/10.1016/j. esp.2012.05.001
Downe-Wamboldt. (1992). Content analysis: Method, applications, and issues. Health Care for Women International, 13(3), 313-321. https://doi. org/10.1080/07399339209516006

EF English Proficiency Index. (2020, December 5). EF English proficiency index A ranking of 100 countries and regions by English skills. https:// www.ef.edu/epi/regions/Europe/netherlands/

Eggins, S. (1994). An Introduction to systemic functional linguistics. Pinter Publisher.

Eggins, S. (2004). An Introduction to systemic functional linguistics (2nd ed.). Continuum.

Ervin-Tripp, S. (1976). Is Sybil there? The structure of some American English directives. Language in Society, 5(1), 25-66. https://doi.org/10.1017/ S0047404500006849

Fikri, Z., Padmadewi, N. N., \& Suarnajaya, I. W. (2014). Mood structure analysis of teacher talk in EFL classroom: A discourse study based on systemic functional linguistic theory. Jurnal Pendidikan Bahasa Inggris Indonesia, 2(1). https://doi.org/10.23887/jpbi.v2i1.1361

Fontaine, L. (2013). Analyzing English grammar: A systemic functional introduction. Cambridge University Press.

Ghadessy, M. (1999). Text and context in functional linguistics. John Benjamins Publishing.

Halliday, M. A. K. (1985). An Introduction to functional grammar. Edward Arnold.

Halliday, M. A. K. (1994). An Introduction to functional grammar (2nd ed.). Edward Arnold.

Halliday, M. A. K., \& Matthiessen, C. M. I. M., (2014). An introduction to functional grammar. Hodder Arnold.

Iedema, R. (1997). The language of administration: Organizing human activity informal institutions. In F. Christie \& J. R. Martin (Eds.), Genre and 
institutions: Social processes in the workplace and school (pp.73-100). Continuum.

Komarawan, Y. (2019). Constructing interpersonal meaning in Indonesia science classrooms through language, space and gaze. KEMANUSIAAN: The Asian Journal of Humanities, 26(1), 1-23. https:// doi.org/10.21315/kajh2019.26.1.1

Krippendorff, K. (2004). Content analysis: An introduction to its methodology (2nd ed.). Sage Publications.

Kuswoyo, H., Sujatna, E. T. S., Indrayani, L. M., \& Rido, A. (2020). Schematic structure and lexicogrammatical features of aerospace engineering English lectures: A systemic functional linguistic approach. Asian EFL Journal, 27(4.6), 171-203.

Lee, J. J. (2016). “There's intentionally behind it...": A genre analysis of EAP classroom lessons. Journal of English for Academic Purposes, 23, 1-14. https://doi.org/10.1016/j.jeap.2015.12.007

Lock, G. (1996). Functional English grammar: An introduction for second language teachers. Cambridge University Press.

Martin, J. R. (2018). Interpersonal meaning: Systemic functional linguistics perspective. Functions of Language, 25(1), 2-19. https://doi.org/10.1075/ fol.17018.mar

Martin, J. R., Matthiessen, C. M. I. M., \& Painter, C. (1997). Working with functional grammar. Arnold.

Moore, M. G. (1989). Editorial: Three types of interaction. American Journal of Distance Education, 3(2), 1-7. http://dx.doi. org/10.1080/08923648909526659

Morell, T. (2004). Interactive lecture discourse for university EFL students. English for Specific Purposes, 23, 325-338. https:// doi:10.1016/ S0889-4906(03)00029-2
Morse, R. (2017, December 5). Best global universities for engineering in the Netherlands. US News and World Report. https://www.usnews.com/ education/best-global universities/netherlands/ engineering

Mukminin, A. (2019). Acculturative experiences among Indonesian graduate students in Dutch higher education. Journal of International Students, 9(2), 488-510. https://doi.org/10.32674/ jis.v0i0.265

Palma, G. (2014). A classroom view of negotiation of meaning with EFL adult Mexican pupils, SAGE Open, 4(2), 1-14. https://doi. org/10.1177/2158244014535941

Qadir, J., Yau, K. A., Imran, M. A., \& Al-Fuqaha. (2020). Engineering education, Moving into 2020s: Essential competencies for effective $21^{\text {st }}$ century electrical and computer engineers. Edarxiv. https://doi.org/10.35542/osf.io/gptse

Quiroz, B. (2018). Negotiating interpersonal meanings: Reasoning about mood. Functions of Language, 25(1), 135-163. https://doi. org/10.1075/fol.17013.qui

Rich, S. (2016). Exploring critical thinking and negotiation of meaning through MinecraftEDU: A case study of elementary language learners [Doctoral dissertation, Boise State University]. Boise State University Theses and Dissertations. https://scholarworks.boisestate.edu/td/1112/

Rido, A. (2017). What do you see here from this picture? Questioning strategies of master teachers in Indonesian vocational English classrooms. TEFLIN Journal, 28(2), 193-211. http://doi.org/10.15639/teflinjournal.v28i2/193211

Rido, A. (2020). Why they act the way they do?: Pedagogical practices of experienced vocational English language teachers in Indonesia. 
International Journal of language Education, 4(1), 24-37. https://doi.org/10.26858/ijole. v4i2.9935

Rido, A., Kuswoyo, H., \& Ayu, R. (2020). Interaction management strategies in English literature lectures in Indonesian university setting. Indonesian Journal of EFL and Linguistics, 5(2), 315-337. http://doi.org/10.21462/ijefl.v5i2.286

Sahan, K. (2020). ELF interaction in English-medium engineering classrooms. ELT Journal, 74(4), 418-427. https://doi.org/10.1093/elt/ccaa033

Schleppegrell, M. J. (2013). The role metalanguage in supporting academic language development. Language Learning, 63(1), 153-170. https://doi. org/10.1111/j.1467-9922.2012.00742.x

Siepmann, D. (2005). Discourse markers across languages: A contrastive study of second level discourse markers in native and non-native text with implications for general and pedagogic lexicography. Routledge.

Soruc, A., \& Griffiths, C. (2017). English as a medium of instruction: Student's strategies. ELT Journal, 73(1), 38-48.

Sujatna, E. T. S. (2013). Mood system and transitivity of the airlines slogan: A comparison of national and regional airlines. International Journal of English Linguistics, 3(3), 42-52. https://doi. org/10.5539/ijel.v3n3p42

Sunardi, S., Tarjana, M. S., Poedjosoedarmo, S., \& Santosa, R. (2018). Interpersonal realizations of pedagogic discourse in Indonesian EFL classrooms. International Journal of Language Teaching and Education, 2(3), 205-215. https:// doi.org/10.22437/ijolte.v2i3.5678

Taghizadeh, M., \& Namayandeh, N. (2020). Engineering students' level on CEFR-based lecture tasks, strategy use, and their problems and attitudes. The Asian ESP Journal, 16(3), 30-63.
Thompson, G. (2014). Introducing functional grammar (3rd ed.). Routledge.

Vinke, A. A., \& Jochems, W. M. G. (1993). English proficiency and academic success in international postgraduate education. Higher Education, 26(3), 275-285.

Walsh, S. (2011). Exploring classroom discourse: Language in action. Routledge.

Waring, H. Z., \& Hruska, B. L. (2012). Problematic directives in pedagogical interaction. Linguistics and Education, 23(3), 289-300. https://doi. org/10.1016/j.linged.2012.06.002

Williams, G. M. (2011). Examining classroom negotiation strategies of international teaching assistants. International Journal for the Scholarship of Teaching and Learning, 5(1), 1-16. https://doi.org/10.20429/ijsotl.2011.050121

Xuan, W., \& Huang, X. (2017). Understanding interpersonal meaning-making in Chinese high school students' ESL writing: A systemic functional perspective. The Asia-Pacific Education Researcher, 26(5), 227- 238. https:// doi.org/10.1007/s40299-017-0343-4

Yuliati. (2012). Interpersonal meaning negotiation in the teacher-student verbal interaction. The International Journal of Social Sciences, 11(1), 52-60. 
